\title{
THE STUDY OF SPINAL DEFORMITY IN TRAUMATIC SPINAL PARALYSIS
}

\author{
By G. M. BeDbrook, M.S., F.R.C.S., F.R.A.C.S. \\ and \\ R. C. Edibam, M.Ch.(Orth), M.S., F.R.C.S. \\ Department of Paraplegia, Royal Perth Hospital, Perth, Western Australia
}

DEFORMITY at the site of fracture dislocation, either cervico-dorsal or lumbo-dorsal, is always a concern to those treating patients with neurological damage at the fracture site. Nicoll (1949) drew attention to the still widely held assumption that anatomical reduction was needed for perfect restoration of function in spinal fractures without paraplegia.

Does the deformity, clinical and radiological, really matter in management programmes?

Should anatomical reduction always be insisted upon?

Are there methods of management which will:

$a$. Reduce the fracture dislocation more satisfactorily initially?

$b$. Maintain such reduction?

What is the functional significance of such methods:

$a$. In the early stages?

$b$. In later stages either generally or locally in the neuraxis?

Such questions need answering by critical study, for the argument on early treatment procedures is still unsolved after 30 years.

\section{PATHOLOgY OF FRACTURE Dislocation AND THE NEURAL CANAL}

$a$. Stripping of the anterior longitudinal ligament with osteogenesis in deep layers.

$b$. Avascular necrosis of bone seen in severe dislocations and crush injuries.

c. Retropulsion of bony tissue is at times a radiological misnomer not always involving the spinal canal.

$d$. One third displacement of a vertebral body does not mean obliteration of the neural canal whose capacity is even then usually adequate to allow cord changes to occur.

$e$. Gross fracture dislocation with gross displacement causes cord avulsion.

\section{COMMENT}

Pathological damage and displacement is:

I. Maximal prior to admission.

2. Difficult to correlate with neural damage at clinical assessment. 


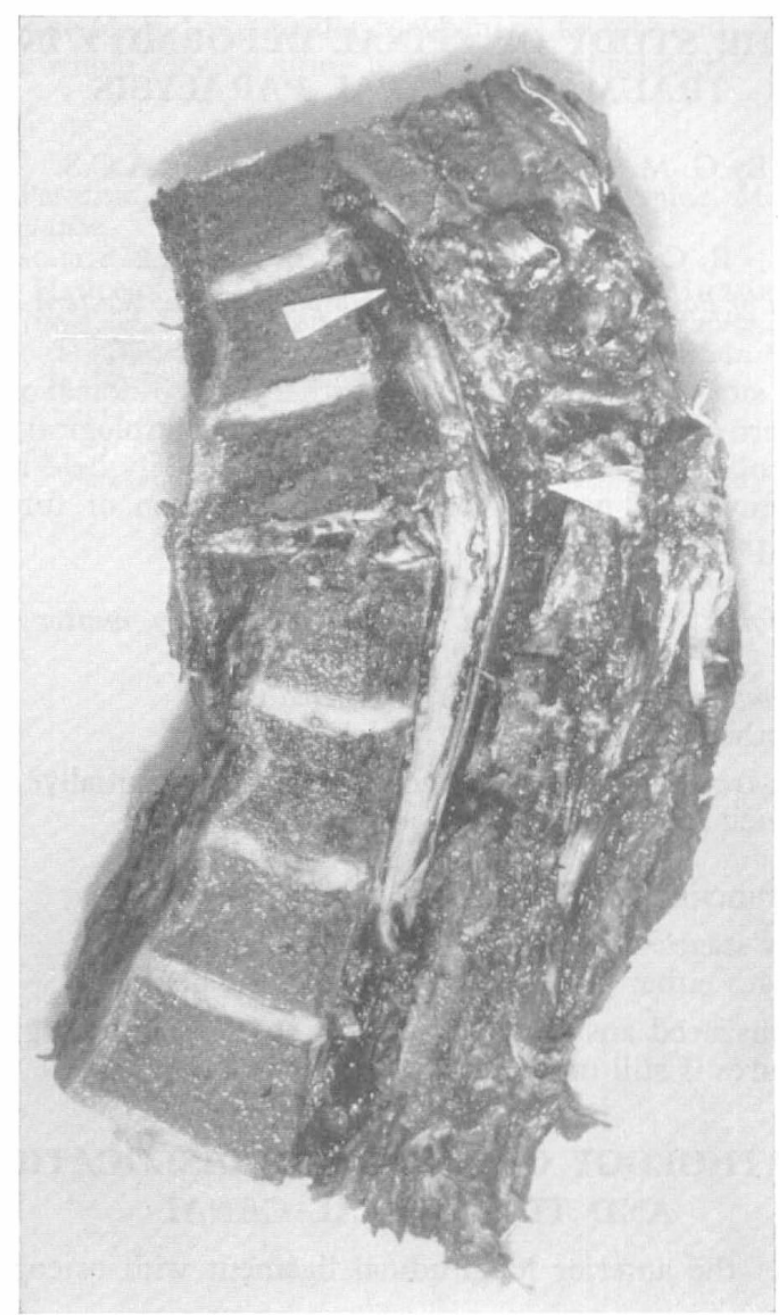

FIG. I

Severe fracture dislocation showing gross displacement with stripped anterior longitudinal ligament.

\section{TABLE I}

Cases Treated by Postural Reduction, Traumatic Cases of Paraplegia, I963-I969

Vertical compression I I

Pure wedge compression with no displacement

Flexion rotation type of injury with varying degrees of displacement and crushing of the vertebral body 
Deformity therefore cannot be accepted without fear of further damage to the neuraxis. Frankel et al. (I969) have, however, documented a few cases where deterioration, which was not always explainable, did occur. Cases can be quoted where increase in deformity in the first few days by injudicious management did cause deterioration, for example:

R. S., aged 28, fracture dislocation TI2/LI, admitted with minor weakness (undiagnosed), developed paraplegia.

\section{TABLE II}

Analysis of 40 Cases (Postural Reduction) of Flexion Rotation Injuries According to Levels

$\begin{array}{lr}\text { Group A: From T2 to T9 } & \text { I5 } \\ \text { Group B: From Tio to L2 } & 23 \\ \text { Group C: From L3 to L5 } & 2\end{array}$

\section{TABLE III}

Correlation of Levels of Injury and C.N.S. State

\begin{tabular}{|c|c|c|c|}
\hline Group & Complete & Incomplete & $\begin{array}{c}\text { Recovery of some neurological } \\
\text { function below the original level }\end{array}$ \\
\hline $\begin{array}{c}\text { Group A: Total I5 } \\
\text { T2-T9 }\end{array}$ & I5 & Nil & Nil \\
Group B: Total 23 & I4 & 9 & I2 \\
Tro-L2 & - & 2 & 2 \\
Group C: Total 2 & - & & \\
L3-L5
\end{tabular}

\section{EARLY DEFORMITIES}

Maximal and minor deformity can be reduced by three major methods.

a. Postural, including the use of traction without anaesthesia-the use of adequate skull traction for cervical injuries, and slow reduction by unlocking techniques if needed. (See Table I.)

$b$. Replacement techniques including the use of general anaesthesia. Such have been condemned by some but subsequent to Mervyn Evans' work and careful follow-up, the method has been proved safe. One case of transitory deterioration occurred in our own series of 493 cases of both cervico-dorsal and lumbo-dorsal cases.

c. Open reduction with or without some type of fixation. Recently the use of posterior spinal supports such as Knodts clamps and Harrington co-aptors and distractors have been advocated. (See Fig. 2.)

There is no doubt that all such methods will usually be successful in over 85 per cent. of severe cases (as was well shown by Frankel et al., 1969). In the first weeks 
active neurological changes occur. By six weeks, however, the changes begin to become fixed and oedema has gone.

Two major groups of cases treated conservatively in many centres then emerge.

I. Those cases rested for 12 weeks or more (Frankel et al., I969).

2. Those who commenced mobility at six to eight weeks, depending on adequate clinical and radiological assessment of stability.

(A third major group whose mobility started at three weeks with or without reduction needs to be studied.)

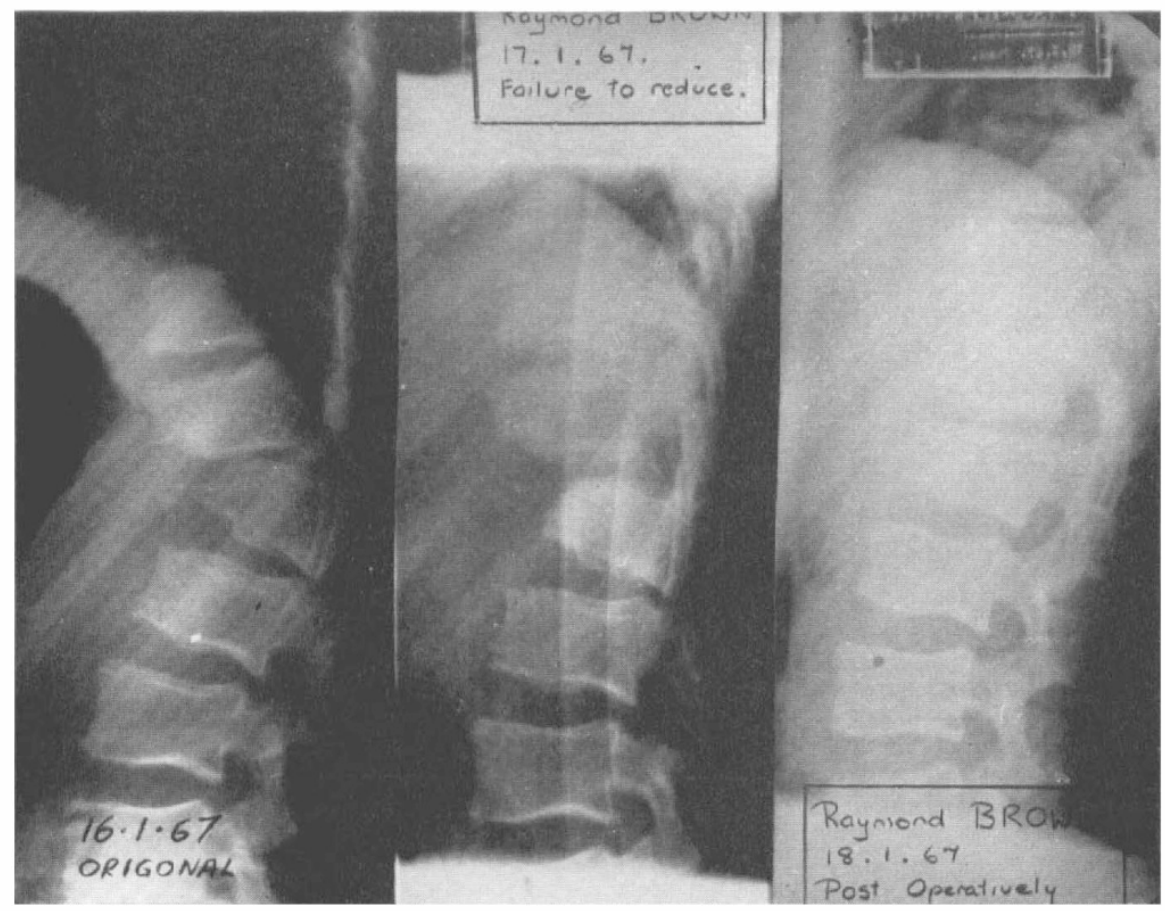

Fig. 2

Gross displacement, failure to reduce by posture; open reduction without fixation.

\section{A. Cervical}

\section{LATE DEFORMITIES}

One small group occurred which gave real concern. Four cases occurred in our cervical series of 199 cases of cervico-dorsal injuries. These were in growing children and this introduced us to a pathological problem of the growing epiphysis, for example:

J. L., male, aged to years at accident. Incomplete tetraplegic C4. Fracture at $\mathrm{C} 4 / 5$. Brown Sequard phenomenon. Could walk on discharge. Quietly over I 8 months he deteriorated as his spine grew into a severe kyphos at $\mathrm{C} 2,3,4$ with the usual tethered cord. He died unrelieved, aged I7 years. (See Fig. 3.) 

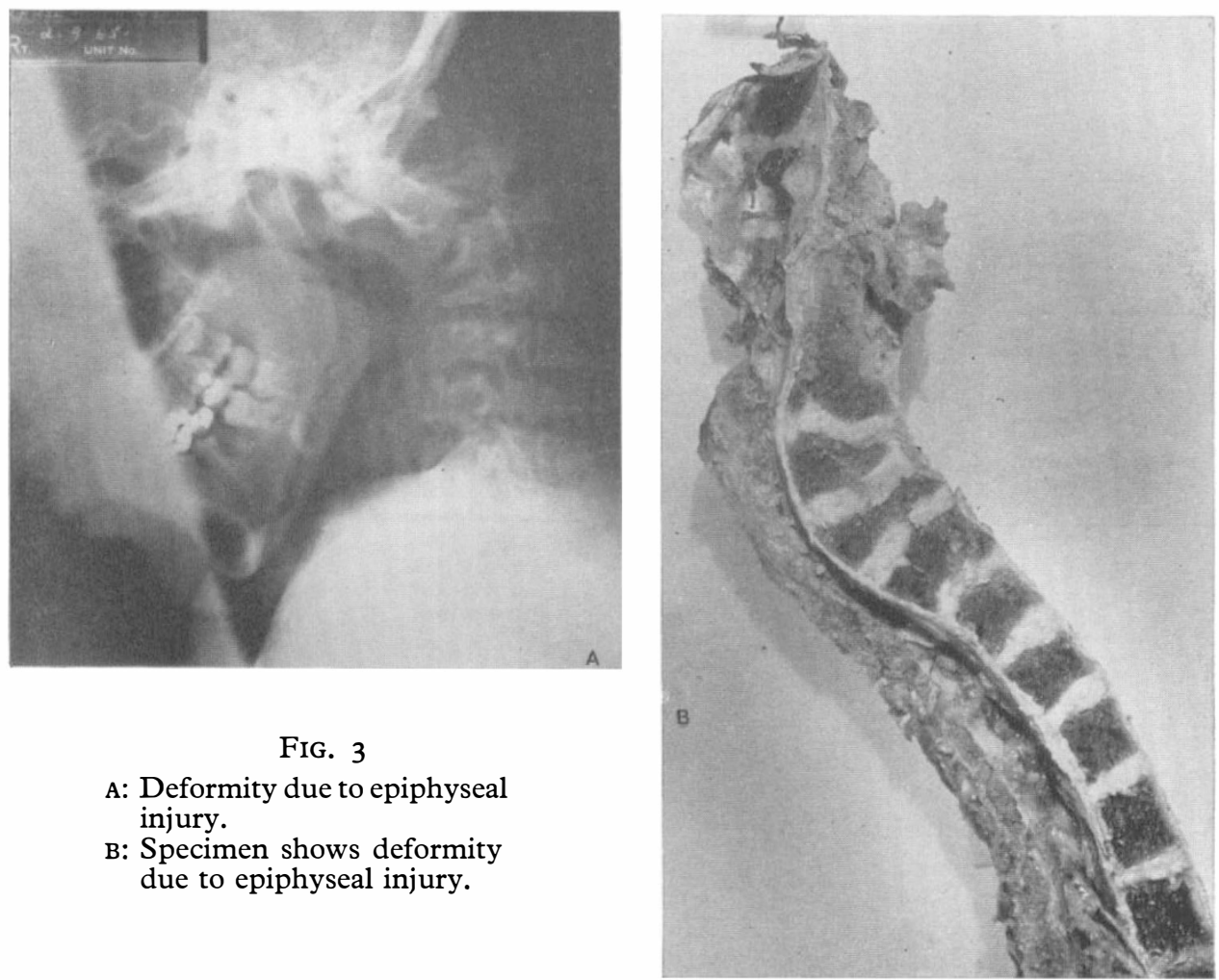

\section{FIG. 3}

A: Deformity due to epiphyseal injury.

B: Specimen shows deformity due to epiphyseal injury.

TABLE IV

Analysis of Severity of Injury

\begin{tabular}{|c|c|c|c|}
\hline $\begin{array}{l}\text { Extent of initial } \\
\text { displacement }\end{array}$ & $\begin{array}{l}\text { Group A } \\
\left(\mathrm{T}_{2}-\mathrm{T}_{9}\right)\end{array}$ & $\begin{array}{l}\text { Group B } \\
\text { (Tio-L2) }\end{array}$ & $\begin{array}{c}\text { Group C } \\
\left(\mathrm{L}_{3}-\mathrm{L}_{5}\right)\end{array}$ \\
\hline $\begin{array}{l}\text { Less than one-third body width } \\
\text { One-third to half body width } \\
\text { Greater than half body width } \\
\text { displacement } \\
\text { Total disruption }\end{array}$ & $\begin{array}{r}3 \\
8 \\
4 \\
-\end{array}$ & $\begin{array}{l}5 \\
6 \\
9 \\
2\end{array}$ & $\frac{2}{-}$ \\
\hline
\end{tabular}

Three other cases in children who showed no signs of spontaneous fusion were fused at six months prophylactically.

\section{B. Lumbo-dorsal}

A series of 40 cases of lumbo-dorsal fractures were carefully studied to assess the results of the postural reduction. (See Tables, II, III, IV, V, VI.) The following facts emerged: 
TABLE V

CORRELATION OF EXTENT OF LATE DEFORMITY

WITH SEVERITY OF INJURY

GROUP A: T.2 - T.9 - 15 CASES

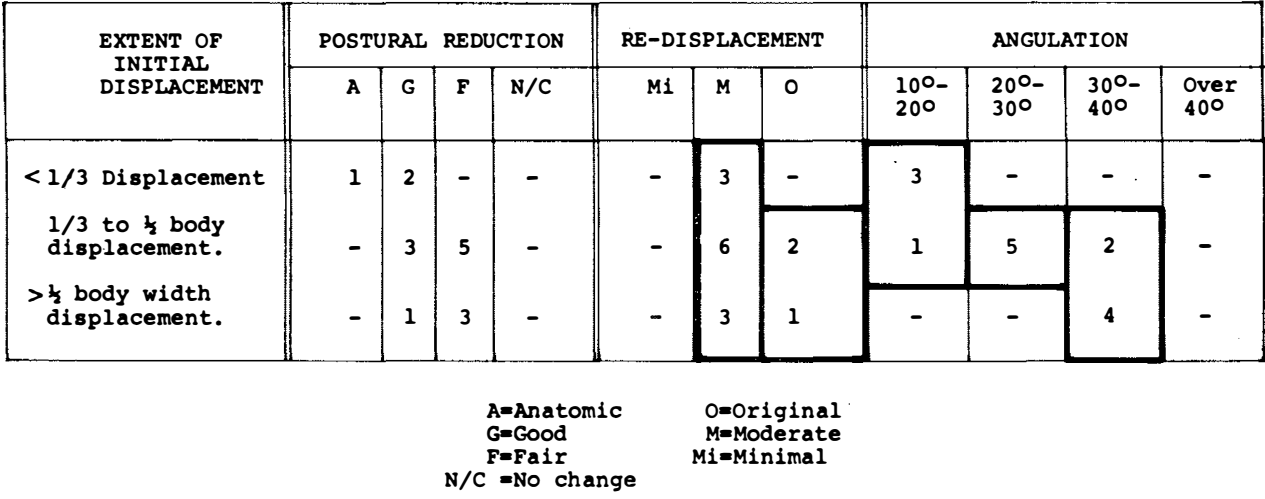

TABLE VI

CORRELATION OF EXTENT OF LATE DEFORMITY

WITH SEVERITY OF INJURY

GROUP B: T.10 - L3. - 23 CASES
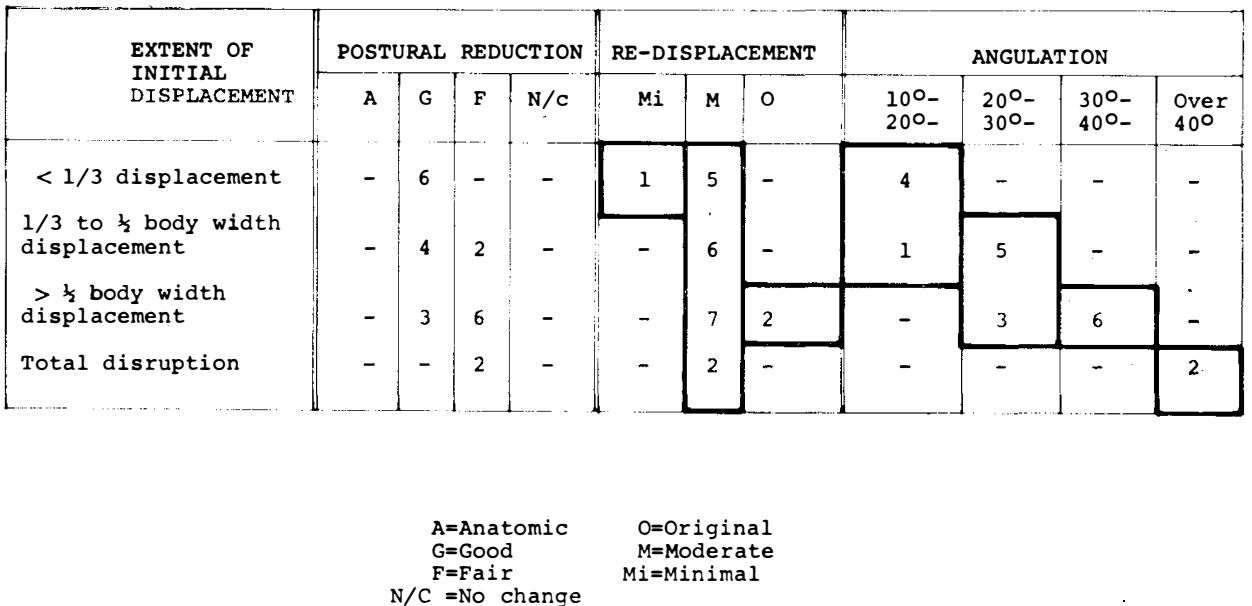

$O=$ Original
M=Moderate

Mi=Minimal

$\mathrm{N} / \mathrm{C}=$ No change

i. Cases nursed on a Stoke Mandeville bed showed less deformity at four and eight weeks than those nursed on conventional beds-six cases not yet included in present series.

ii. All initially greater than half body displacements, redisplaced and collapsed (II out of 40) and always had final deformity. (See Tables V, VI.) 


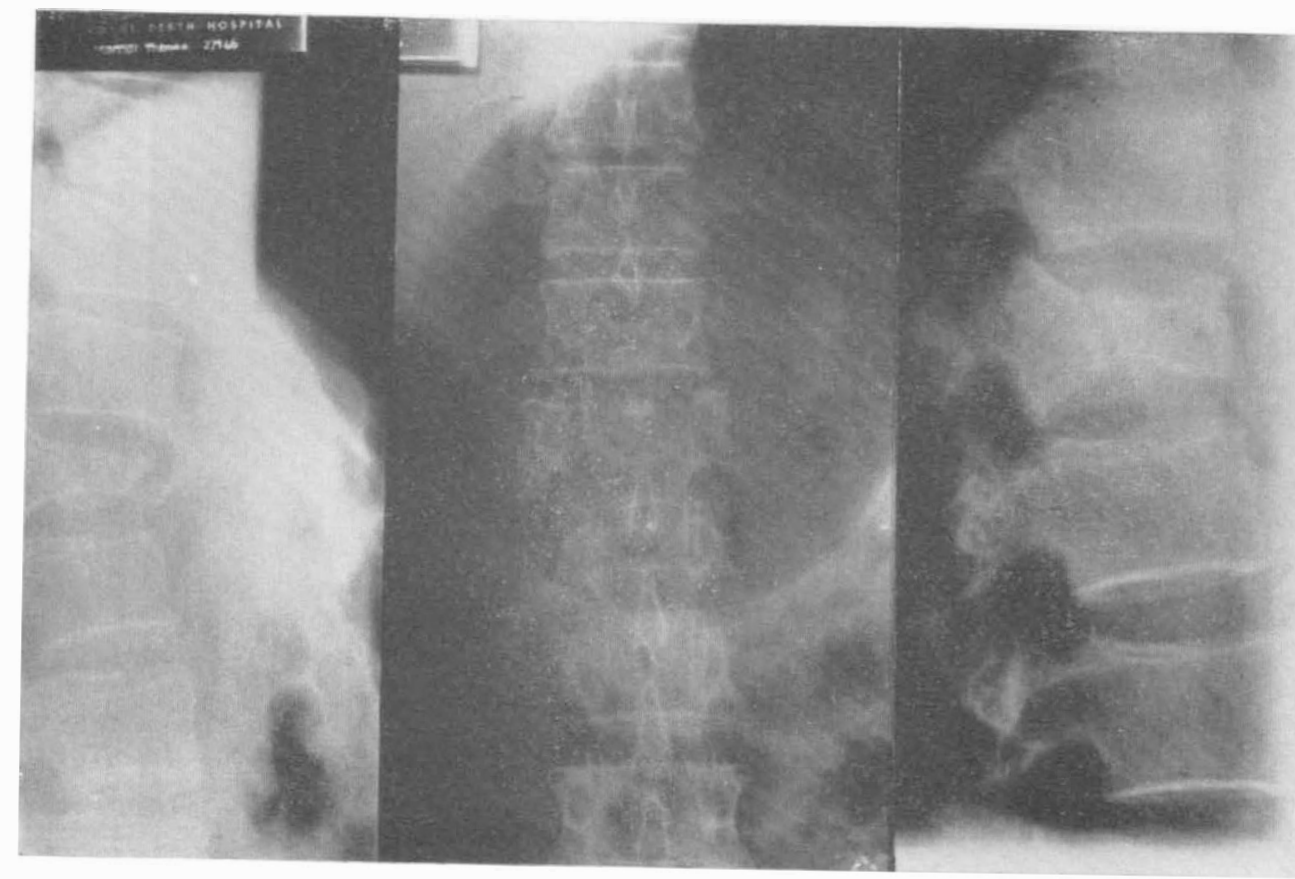

FIG. 4

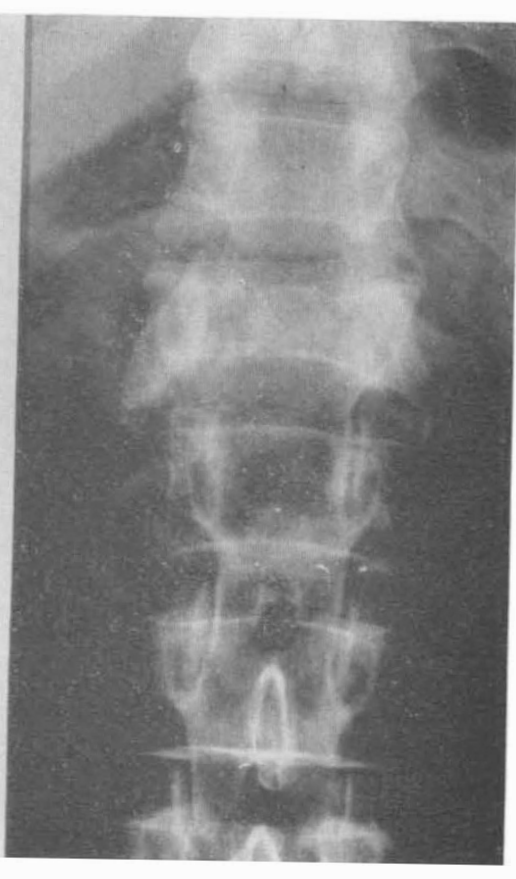

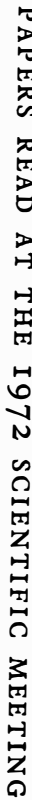

TI2-Li fracture dislocation with less than one-third displacement. Reduction stable. Good remodelling. 


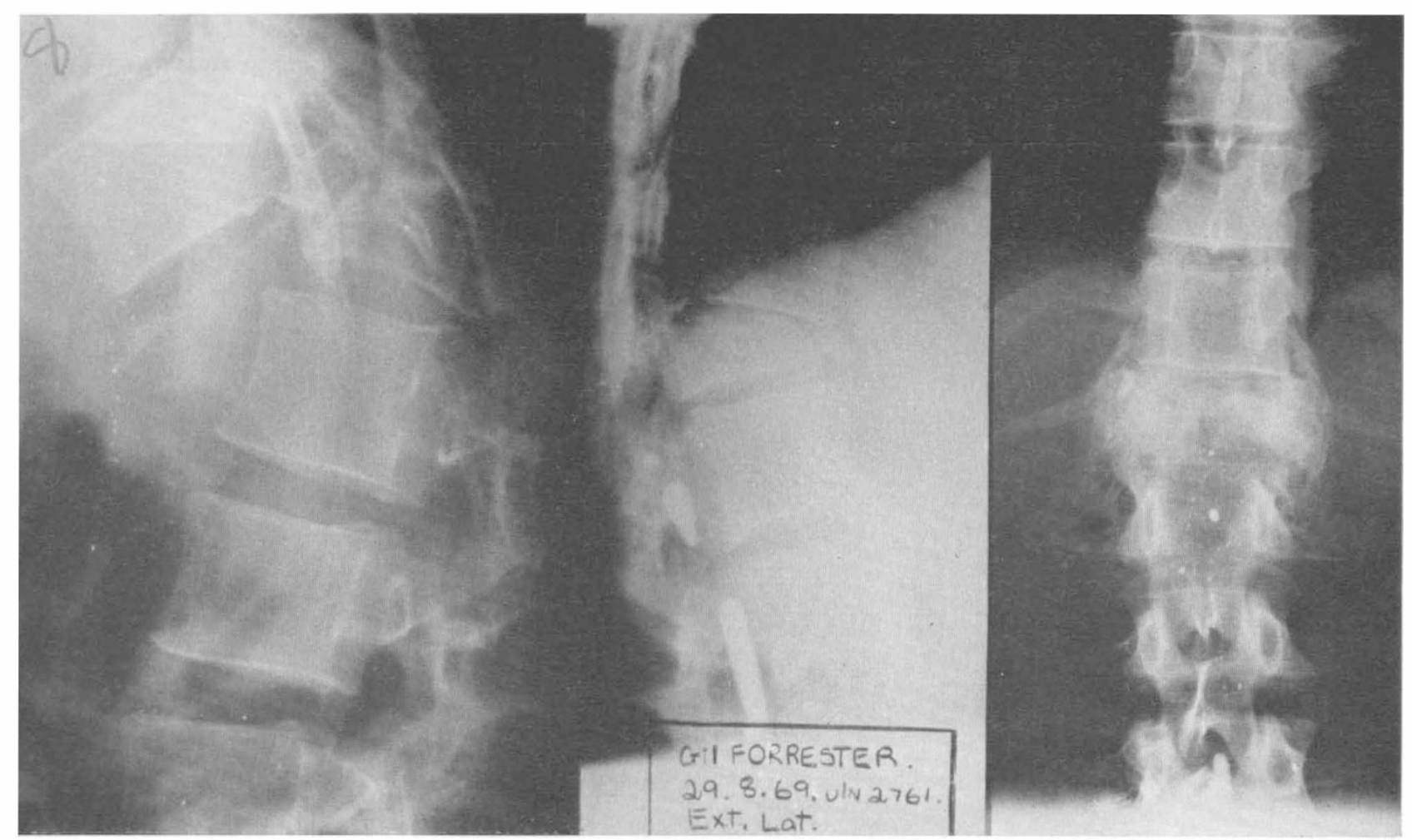

FIG. 5

Severe TII on TI2 fracture dislocation, final severe compression but redisplacement not greater than one-third. 
iii. Cases with deformity of one third or less, and all true compression cases never showed gross deformity, in fact they were the commonest anatomical 'reductions'. (See Fig. 4.)

iv. All 40 cases had adequate postural reduction (less than one third displacement) but by three months most cases had displaced and collapsed again but not as great as initially. The greater the initial displacement and crushing the greater the final deformity. (See Tables V and VI.)

v. Spinal cord function could not be compiled as insufficient numbers were studied. Redisplacement did not impede good recovery in one later case (not in series)

\section{TABLE VII}

Assessment of Spinal Union

\begin{tabular}{|c|c|c|c|c|c|c|c|}
\hline $\begin{array}{l}\text { No. of } \\
\text { cases }\end{array}$ & Type of injury & $\begin{array}{l}\text { Appearance } \\
\text { of para- } \\
\text { vertebral } \\
\text { callus at } \\
6 \text { weeks }\end{array}$ & $\begin{array}{l}\text { Fusion } \\
\text { at } 3 \\
\text { months }\end{array}$ & $\begin{array}{l}\text { Fusion } \\
\text { at } 6 \\
\text { months }\end{array}$ & $\begin{array}{l}\text { Fusion } \\
\text { at I2 } \\
\text { months }\end{array}$ & $\begin{array}{l}\text { Fusion } \\
\text { at } 2 \\
\text { years }\end{array}$ & $\begin{array}{l}\text { No } \\
\text { fusion }\end{array}$ \\
\hline $\begin{array}{l}\text { II } \\
7 \\
40\end{array}$ & $\begin{array}{l}\text { Vertical } \\
\text { compression } \\
\text { Simple wedge } \\
\text { compression } \\
\text { Flexion } \\
\text { rotation } \\
\text { injuries }\end{array}$ & $\begin{array}{r}6 \\
-\end{array}$ & $\begin{array}{l}5 \\
\text { I }\end{array}$ & 一 & - & - & - \\
\hline
\end{tabular}

vi. Only two cases out of 40 had non-union at the end of one year although in 23 cases of severe dislocations all had further collapsed. (See Table VII.)

vii. Only one case had a gibbus which caused a problem for management. No gibbus had any effect on neurological states as far as could be found.

viii. Only four cases had local spinal pain: two non-union and two disc degeneration above the fracture site. (See Table IX.)

ix. The greater the injury the greater the callus in the postural series (34 of 40) (See Table VII.)

x. Follow-up of five years showed that spinal mobility had not deteriorated nor was there any marked incidence of:

I. Local pain. (See Table VIII.)

2. Further increase in deformity (in fact a remodelling and further fusion proceeded).

xi. Mobilisation at six weeks did not cause neurological function to deteriorate, and allowed greater rehabilitative mobility. Deformity had already occurred in this series by the third week in hospital, despite good early reduction and postural maintenance. 
TABLE VIII

Late Spinal Pain

\begin{tabular}{|c|c|c|c|c|}
\hline No. & Type of fracture & $\begin{array}{l}\text { Persistent pain } \\
\text { after } 3 / 52\end{array}$ & $\begin{array}{l}\text { Persistent pain } \\
\text { at I year }\end{array}$ & $\begin{array}{l}\text { Persistent pain } \\
2 \text { years } \& \text { over }\end{array}$ \\
\hline \multirow{4}{*}{$\begin{array}{r}\text { I I } \\
7 \\
40\end{array}$} & \multirow{4}{*}{$\begin{array}{l}\text { Vertical compression } \\
\text { Wedge compression } \\
\text { Flexion rotation injuries } \\
\text { with displacement }\end{array}$} & Nil & Nil & Nil \\
\hline & & Nil & Nil & Nil \\
\hline & & & & \\
\hline & & 4 & 2 & 2 \\
\hline
\end{tabular}

2 cases had anterior spinal fusion to relieve their pain.

TABLE IX

Clinical Appearance of Deformity and Skin Complications as a result of Deformity

\begin{tabular}{|c|c|c|c|c|c|c|}
\hline No. & Type of injury & Nil & Mild & Moderate & Severe & $\begin{array}{l}\text { Skin complications } \\
\text { over gibbus }\end{array}$ \\
\hline $\begin{array}{r}\text { I I } \\
7 \\
40\end{array}$ & $\begin{array}{l}\text { Vertical } \\
\text { compression } \\
\text { Wedge } \\
\text { compression } \\
\text { Flexion rotation } \\
\text { injuries with } \\
\text { displacement }\end{array}$ & $\begin{array}{r}\text { I0 } \\
4\end{array}$ & $\begin{array}{r}\text { I } \\
3 \\
36\end{array}$ & $\begin{array}{l}- \\
-\end{array}$ & $\begin{array}{l}- \\
-\end{array}$ & $\begin{array}{l}\text { Nil } \\
\text { Nil }\end{array}$ \\
\hline
\end{tabular}

TABLE X

Analysis of 30 Cases Treated by Internal Fixation

\begin{tabular}{|c|c|c|c|c|c|}
\hline Group & Levels & Numbers & $\begin{array}{c}\text { Type of } \\
\text { lesion } \\
\text { complete }\end{array}$ & $\begin{array}{c}\text { Type of } \\
\text { lesion } \\
\text { incomplete }\end{array}$ & Recovery \\
\hline A & T2 T9 & 8 & 7 & I & I \\
B & Tro L2 & I9 & 9 & I0 & 4 \\
C & L3 L5 & 3 & - & 3 & 3 \\
\hline
\end{tabular}

C. Other Methods of Management

A colleague has now made a preliminary study of 58 cases treated initially:

a. By no treatment at all-28 cases.

$b$. At a centre where all lumbo-dorsal cases are operated upon without laminectomy but with internal splintage (30 cases) by Knodts clamps, Harrington co-aptors and Meurig Williams plates. 
Studies to date in this series of 58 cases show by comparison to our own 40 studied cases:

I. All cases in postural group had back pain durings posturing, severe-Io days moderate-three weeks when deformity is believed to recur. In the internally fixed group it was claimed that all cases immediately became more comfortable-this remains to be further tested.

2. Those treated by compression devices posturally with adequate fixation by two clamps tended not to displace. (See Table XIII.) Eight out of eight cases in Group A, and nine out of Io in Group B. This can be compared to the postural group where in all cases some displacement occurred.

3. Comparison of the wedging as distinct from displacement on final X-rays in both groups showed a similar incidence, e.g. $20^{\circ}-40^{\circ}$. Twelve of 48 in Tables V and VI and five of 18 in Table XIII, approximately one third in each series.

\section{TABLE XI}

Analysis of Cases According to the Types of Internal Fixation

\begin{tabular}{|c|c|c|c|c|}
\hline Groups & $\begin{array}{c}\text { Murig Williams } \\
\text { plates }\end{array}$ & L. Knodts clamps & $\begin{array}{c}\text { Single Knodts } \\
\text { clamp }\end{array}$ & $\begin{array}{c}\text { Interspinous } \\
\text { wiring }\end{array}$ \\
\hline A & - & 8 & - & - \\
B & 9 & Io & - & I \\
C & - & - & 3 & \\
\hline
\end{tabular}

4. Of the small group treated by Meurig Williams plates, in early stages only one out of eight showed $20^{\circ}$ to $40^{\circ}$ wedging and became infected showing the known futility of this method.

5. In the series treated by open reduction the union rate appeared slower. The study is not really adequate in depth or numbers at present.

Nicoll (1949) in his assessment of mining accidents used the criterion of $\mathrm{X}$-ray measurements and ability to work at coal face as measures. As in nonparaplegic cases the factors in redisplacement of paralytics in this group are:

a. Comminution of the vertebral body.

$b$. Crushing of the intervertebral disc.

c. The integrating of the posterior ligament complex.

Nicoll (1949) showed best results functionally in those treated without any fixation. He concluded that in paraplegics no dogmatic statement could then, in 1949, be made. He further concluded that in non-paraplegics the assumption of the need for anatomical reduction was unproved and in fact was a fallacy.

Most of the protagonists of a I2-week bed therapy claim better results and less redisplacement and wedging. The results of Frankel et al. (1969). Guttmann (I953), Hardy (I972) and Walsh (I972) seem to be comparable, while an extra six weeks' bed rest does not appear to have such benefit functionally. This was 
TABLE XII

Assessment of the Effectiveness of Internal Fixation

I. Meurig Williams Plating

\begin{tabular}{|c|c|c|c|c|c|c|c|c|c|c|}
\hline \multirow[b]{2}{*}{ Groups } & \multirow[b]{2}{*}{ Numbers } & \multicolumn{3}{|c|}{ Reduction } & \multirow{2}{*}{$\begin{array}{l}\text { Maintenance } \\
\text { of reduction }\end{array}$} & \multicolumn{3}{|c|}{ Wedging deformity } & \multirow[b]{2}{*}{ Union } & \multirow[b]{2}{*}{ Infection } \\
\hline & & A.N.A. & Good & Fair & & $10-20$ & $20-40$ & $\begin{array}{c}\text { Over } \\
40\end{array}$ & & \\
\hline A & - & - & - & - & $\ldots$ & 一 & - & - & — & — \\
\hline B & 8 & I & 5 & 2 & I & $\cdots$ & 8 & - & 6 & 2 \\
\hline $\mathrm{C}$ & - & - & - & - & 一 & -.. & - & $一$ & $-\ldots$ & - \\
\hline
\end{tabular}

TABLE XIII

Assessment of the Effectiveness of Internal Fixation

II. Knodts Clamps \& Harrington Co-apters

\begin{tabular}{|c|c|c|c|c|c|c|c|c|c|c|}
\hline \multirow[b]{2}{*}{ Groups } & \multirow[b]{2}{*}{ Numbers } & \multicolumn{3}{|c|}{ Reduction } & \multirow{2}{*}{$\begin{array}{l}\text { Maintenance } \\
\text { of reduction }\end{array}$} & \multicolumn{3}{|c|}{ Wedging deformity } & \multirow{2}{*}{$\begin{array}{l}\text { Union } \\
\text { at I year }\end{array}$} & \multirow[b]{2}{*}{ Infection } \\
\hline & & A.N.A. & Good & Fair & & $10-20$ & $20-40$ & $\begin{array}{c}\text { Over } \\
40\end{array}$ & & \\
\hline $\begin{array}{l}\text { A } \\
\text { B } \\
\text { C }\end{array}$ & $\begin{array}{r}8 \\
\text { I0 } \\
3\end{array}$ & $\begin{array}{l}5 \\
8 \\
3\end{array}$ & $\begin{array}{r}3 \\
2 \\
-\end{array}$ & 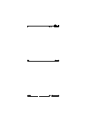 & $\begin{array}{r}8 \\
9 \\
\end{array}$ & $\begin{array}{l}5 \\
8 \\
3\end{array}$ & $\begin{array}{r}3 \\
2 \\
-\end{array}$ & - & $\begin{array}{l}2 \\
\text { I } \\
2\end{array}$ & - \\
\hline
\end{tabular}


particularly so when in these 40 cases redisplacement was common at three weeks, despite careful and critical re-valuation of postural methods.

The argument regarding methods of early management of lumbo-dorsal fractures with paraplegia has not been completely resolved despite many investigations and much time spent. We still have the advocate of so-called internal fixation. Guttmann's contribution of postural reduction as a method of choice has not been universally accepted. Surgeons are frequently content to be technicians without critical review. The recent review by Frankel and his co-workers represents the, as yet, most critical review of 6I 2 cases treated by postural methods. No comparable series treated by any other means exists. Until such is done the argument will continue.

One factor that is hard to assess is pain in the early stages. This still remains as one feature to be investigated, for modern methods of internal splintage by Knodts clamps and Harrington co-aptors have not the original objections of plates, because:

I. They give local fixation of two to three segments only;

2. They do not need wide exploration; the accident provides the exposure by muscle stripping;

3. A series of patients observed in Adelaide, South Australia, were being so treated. While we do not agree with the surgical indications, they were nevertheless comfortable and considerably more free of pain in initial stages than in our own 40 cases treated by orthodox conservative measures: particularly the severe greater than half displacement group. The Stoke Mandeville bed is we believe an answer to this, but for many this may be financially impossible. To try to be more specific we believe further study is required by use of the Analysis Proforma Sheet used by Frankel and co-workers, and by detailed follow-up in a truly comparable series, treated otherwise in a similar manner.

\section{CONCLUSION}

A. Deformity in early stages is certainly significant and should be reduced to allow cord sparing to recover under optimal pathological conditions.

B. In the later states:

i. In a small cervical group, deformity is highly significant, in the end result, re deformity and neurological state.

ii. At the lumbo-dorsal junction our preliminary study indicated deformity (rarely greater than $40^{\circ}$ ) and is not significant to good function. In fact, old cases with gross deformity of over $40^{\circ}$ were noted with no pain and good mobility.

C. All cases with deformity could be related to bony pathological changes. Furthermore, union was shown as a greater and better than the early follow-up of operated cases.

D. Deformity should be studied in two ways:

i. Examination of redisplacemnt compared with original.

ii. The measuration of later wedging, dependent on the bony pathology. 


\section{SUMMARY}

With the accumulated evidence at present available we believe that long term function, both clinical, in regard to tolerance of time in a wheelchair, and neurological, show that deformity up to a moderate degree can be accepted without fear of adversely influencing the results.

\section{REFERENCES}

Bedbrook, G. M. (1963). Int. F. Paraplegia, 1, 2 I6.

Frankel, H. L., Hancock, D. O., Hyslop, G., Melzak, J., Michaelis, G. H., Ungar, G. H., Vernon, J. D. S. \& Walsh, J. J. (I969). Int. F. Paraplegia, 7, I79.

Guttmann, L. (1953). Medical History of the Second World War: Surgery (edited by Sir Zachary Cope), pp. 422-5I6. London: H.M. Stationery Office.

HARDY, A. (I972). Personal communication.

Nicoll, E. A. (1949). F. Bone and foint Surg. 31B, 376.

WALSH, J. J. (1972). Personal communication.

Watson-JoNes, R. (1952). Fractures and foint Injuries. 6th Ed. 1965. Edinburgh: E. \& S. Livingstone

\section{Discussion}

Mr. W. KeRR (G.B.). I should like to ask Mr. Bedbrook further details about his mention of work by Nicoll. This person's work concerns a very firm division of spinal injuries into functionally treated stable fractures, and unstable fractures which must be kept stabilised. If a patient is ambulant with no neurological damage, they can be put in a plaster jacket or spinal fusions can be performed, but only Nicoll, as far as I know, treats functionally those patients who have had a simple wedge compression of the vertebra with no displacement and certainly no damage to the posterior elements. I don't think there should be confusion with Nicoll's work and the slides that we saw of definitely unstable fractures.

Mr. T. McSwEENEY (G.B.). I'd like to comment on the papers of Dr. Braakmann and Mr. Bedbrook. There may seem to be some slight conflict here. First of all I'd like to agree wholeheartedly with Dr. Braakmann in making a distinction in the occurrence of progressive neurological signs and delayed myelopathy-the distinction here between the patient who is admitted with gross neurological features and the patient who attends an orthopaedic surgeon with minimal neurological signs. I think delayed myelopathy is much commoner in the latter group. Because this might appear to conflict with the very important paper of George Bedbrook's, where, and I think I get him correctly, he would adopt a more laissez faire attitude to deformity, particularly outside the cervical spine, than Dr. Braakmann. In fact, he is so laissez faire as to be reminiscent of Lucas Champonier, who would scarcely apply a mobilisation to a fracture. Now I think, like George Bedbrook, that the functional result of the average spinal injury is better if there has been no surgical intervention. On the question of later myelopathy, I do not think that angulation at the site of injury is the source of the myelopathy, rather it is at a distance, and the deformity of the resultant myelopathy is not associated with the deformity but some other process, and that process is at distance from the site of angulation.

Dr. R. BRAakmann (The Netherlands). I would like to have some discussion with Mr. Bedbrook and Mr. McSweeney on this topic, but most people I think are waiting for lunch, and I'm getting hypoglycaemic, so I'll make no further comments. 